
\title{
28 Research Suare \\ Living Particulate Fluxes in Throughfall and Stemflow During a Pollen Event
}

\section{Michele Guidone}

Georgia Southern University - Armstrong Campus

D. Alex R. Gordan

Georgia Southern University

John Toland Van Stan ( $\sim$ jvanstan@georgiasouthern.edu )

Georgia Southern University https://orcid.org/0000-0002-0692-7064

\section{Short Report}

Keywords: Pollen, Phyllosphere, Rainfall, Precipitation partitioning, Metazoans, Particulates

Posted Date: February 15th, 2021

DOI: https://doi.org/10.21203/rs.3.rs-230397/v1

License: (c) (1) This work is licensed under a Creative Commons Attribution 4.0 International License.

Read Full License

Version of Record: A version of this preprint was published at Biogeochemistry on April 1st, 2021. See the published version at https://doi.org/10.1007/s10533-021-00787-7. 


\section{Short Communication}

2 Living particulate fluxes in throughfall and stemflow during a pollen event.

3 Michele Guidone ${ }^{1,2}$, D. Alex Gordon ${ }^{2,3}$, and John T. Van Stan II,3,+

41 Biology, Georgia Southern University, Savannah, GA, USA

$5 \quad 2$ Applied Coastal Research Laboratory, Georgia Southern University, Savannah, GA, USA

$6{ }^{3}$ Geology \& Geography, Georgia Southern University, Savannah, GA, USA

$7+$ https://orcid.org/0000-0002-0692-7064

8 Corresponding author: professor.vanstan@gmail.com

Abstract: Pollen shedding can produce rapid, abundant exchanges of nutrient-rich biomass from plant canopies to the surface. When pollen deposits onto understory plants, it can be washed off during storms via throughfall (a drip flux) and stemflow (a flux down plant stems). Pollen deposition may also alter the organismal community on plant surfaces, changing other biological particulates transported by throughfall and stemflow. We report concentrations and fluxes of pollen and other biological particulates (flagellate cells, nematodes, rotifers, mites and hexapodans) in throughfall and stemflow from an understory forb, Eupatorium capillifolium (Lam. dogfennel), during a Pinus palustris (Mill. longleaf pine) pollen shedding event, then compare these results to observations collected when pollen was absent. Pollen flux was $95.6 \mathrm{x}$ $10^{6}$ grains ha $^{-1}$ season $^{-1}$ from dogfennel canopies ( $63 \%$ and $37 \%$ transported by throughfall and stemflow, respectively), representing 0.1-3.2 $\mathrm{g} \mathrm{ha}^{-1}$. Median concentrations in flagellates, nematodes and rotifers for throughfall and stemflow were higher during pollen shedding; however, mites and hexapodan concentrations were similar regardless of pollen presence. This is the first report of flagellate and hexapodan concentrations in canopy drainage waters. Flagellate concentrations were higher than for other organisms-being similar to those reported for streams, $10^{5}-10^{7}$ cells $\mathrm{L}^{-1}$-and hexapodan fluxes were $\sim 50$ individuals $\mathrm{m}^{-2}$ per $1 \mathrm{~cm}$ of rainfall. These results indicate that throughfall and stemflow can (i) transport ecologically relevant amounts of pollen and organisms from the phyllosphere to the surface, and (ii) that

27 the composition and flux of biological particulates can change markedly during pollen shedding. 
Introduction.

Forest canopies can shed $10^{1}-10^{3} \mathrm{~kg} \mathrm{ha}^{-1}$ of pollen over a short period of time-days, weeks or months-depending on the plant species and meteorological conditions (e.g., Boyer, 1981; Doskey and Ugoagwu, 1989; Greenfield, 1996; Lee et al., 1996; Cho et al., 2003; Lee and Booth, 2003). This relatively rapid and abundant canopy-to-surface exchange of biomass can play important roles in the biogeochemistry of the canopy and receiving aquatic and terrestrial systems. Pollen macronutrient concentration is relatively high, being 2-5 times greater than litterfall (Stark, 1973; Lee et al., 1996). The unique stoichiometry of pollen can result in the release of biolabile material after deposition to detrital and freshwater systems (Rösel et al., 2012; Masclaux et al., 2013; Filipiak, 2016). Pollen is enriched in N and (especially) P compared $\mathrm{ha}^{-1} \mathrm{y}^{-1}$ (Perez-Moreno and Read, 2001) - an amount that exceeds annual $\mathrm{N}$ recycled by litterfall in some forests (Greenfield, 1999)-and the few observations to date suggest pollen is readily

42 mineralized (Greenfield, 1999; Webster et al., 2008). Pollen P concentrations can be three times those of desert dust aerosols (Bigio and Angert 2018) and pollen P also may be rapidly released by microbial communities (Graham et al., 2006; Filipiak, 2016).

A portion of shed pollen will not directly access the litter layer or nearby aquatic understory vegetation (Millerón et al., 2012). This has nontrivial effects on the phyllosphere. Pollen can contain unique microbial communities (e.g., Ambika Manirajan et al., 2016; Kim et al., 2018) and, thus, the coating of the phyllosphere by pollen shedding events can influence the 
51 particles (e.g., Hutchison and Barron, 1997; Magyar et al., 2018). Pollen also ephemerally alters

52 the invertebrate community visiting the phyllosphere, i.e., pollinators (Aleklett et al., 2014;

53 Kwon et al., 2018). Thus, rainfall during and after pollen events is hypothetically altered in its

54 particulate composition by draining through this transitorily unique phyllosphere-beyond the

55 simple washing of pollen particles. To the authors' knowledge, however, no research has tested

56 this hypothesis to date.

The passage of rainwater through plant canopies generally results in a significant

58 transfer of solutes and particulates (Ponette-Gonzalez et al., 2020), both as a drip flux from

59 canopy surfaces (throughfall) and a contact flow down the outside of plant stems (stemflow).

60 During (non-pollen) storms, throughfall and stemflow have been reported to transport to the

61 forest floor quadrillions of bacterial cells ha-1 (Bittar et al., 2018), billions of fungal spores ha-1

62 (Van Stan et al., 2021), and stemflow alone has been estimated to transport millions of 63 metazoans ha-1 (Ptatscheck et al., 2018). In this short communication, we present and briefly 64 discuss pollen, flagellated protist, and invertebrate animal concentrations and fluxes in 65 throughfall and stemflow from a common and North American understory and pasture forb, 66 Eupatorium capillifolium Lam. (dogfennel) during a Pinus pallustris Mill. (longleaf pine) pollen 67 shedding event (February-March 2019).

\section{Methods.}

The study was conducted in a forest fragment in Statesboro, Georgia, USA, at Georgia Southern University's main campus (32.430 N, -81.784 W, 65 m A.S.L.). Climate is subtropical (Köppen Cfa), 30-year mean annual precipitation is $1,170 \mathrm{~mm} \mathrm{y}^{-1}$ spread relatively evenly 
72 throughout the year (University of Georgia, 2019). The overstory is dominated by P. palustris

73 (223 trees ha-1) and the understory is dominated by dogfennel $\left(56,770\right.$ stems ha-1 $\left.{ }^{-1}\right)$. See Gordon

74 et al. (2020) for more information on the study site. Pollen shedding from P. palustris occurred

75 at the site during February-March 2019. During this time, 5 rain events occurred whereafter

76 stemflow and throughfall water samples were collected from the dogfennels. For comparison,

77 water samples were collected from 2 storms during non-pollen conditions (in October 2019).

Three dogfennel clumps were randomly selected for throughfall and stemflow

79 monitoring. Within these three clumps, 30 individual dogfennel stems were randomly selected

80 for stemflow monitoring. Throughfall gauges consisted of 9 randomly placed funnels $\left(506.7 \mathrm{~cm}^{2}\right.$

81 collection area each)-three per dogfennel clump $\left(1,520.1 \mathrm{~cm}^{2}\right.$ total collection area per

82 clump)-connected to HDPE bottles that were manually measured with graduated cylinders

83 immediately after a storm ended (within $4 \mathrm{~h}$ ). Stemflow collars were constructed from

84 aluminum foil, $15-\mathrm{mm}$ inner-diameter flexible polyethylene tubing, electrical tape, and silicon

85 thinned with hydrotreated light (95-100\%) naphtha (VM\&P Naphtha, Klean-Strip, Memphis TN

86 USA) (same as Gordon et al., 2020). Stemflow volume was measured with a graduated pipette

87 (with $1 \mathrm{~mL}$ graduations) from $500 \mathrm{~mL}$ plastic bottles connected to the tubing base. All samplers were pre-cleaned with $\mathrm{pH} 2$ ultrapure water, triple-rinsed, air dried, and covered until the start

89 of a rainfall event. All samples collected for pollen, flagellated protist, and invertebrate analysis

90 were immediately placed into refrigeration $\left(\sim 4^{\circ} \mathrm{C}\right)$ until being processed. Three volume-

91 weighted composite samples of stemflow and throughfall-one for each dogfennel clump-

92 were examined per storm. 
Average pollen density per water sample was determined by examining three or four

94 (depending on total volume) $30 \mu \mathrm{l}$ subsamples using a compound light microscope (Motic

BA210E) at 100x total magnification. Similarly, the per sample average unicellular flagellate density was determined for three or four $10 \mu \mathrm{l}$ subsamples counted using a hemocytometer

97 viewed under the microscope at $400 x$ total magnification. All water samples were mixed via a vortexer (FisherBrand Analog Vortex) for approximately $5 \mathrm{~s}$ prior to taking each subsample. Invertebrates were quantified by examining the entire remaining water sample in small, 100 subsectioned portions using the dark field setting of a dissecting microscope (Olympus SZX16) 101 and a minimum total magnification of $40 x$.

Data were analyzed for descriptive statistics of central tendency and variability. To assess whether and to what extent correlation exists between particulate types, Spearman $\rho$ 104 tests were performed between mean pollen, flagellate, and invertebrate densities $\mathrm{L}^{-1}$ of 105 throughfall and stemflow. No statistical difference testing was performed due to the limited 106 number of samples examined per storm. All statistical analyses were done in JMP Pro v. 13.

\section{Results and discussion.}

During pollen shedding, throughfall and stemflow generally had concentrations of 1-6 $x$

$10910^{5}$ pollen grains $\mathrm{L}^{-1}$, but zero-to-negligible pollen concentrations were observed in October 110 (Figure 1a). Overstory throughfall estimations (from the $P$. palustris overstory) ranged from 3.5-

$11144.1 \mathrm{~mm}^{-2 v e n t} \mathrm{t}^{-1}$ and dogfennel canopies partitioned this into $36-76 \%$ throughfall and 5-67\%

112 stemflow per event (Table S1, Supplemental Materials). Note that the $67 \%$ stemflow estimate 113 resulted from additional occult precipitation. Given these water flux estimates, the total pollen 
114 flux across the 5 storms was $95.6 \times 10^{6}$ grains ha- ${ }^{-1}$, where $63 \%$ and $37 \%$ were transported by

115 throughfall and stemflow, respectively. To estimate pollen mass flux draining from the 116 dogfennel understory, we could find no reports of individual pollen grain mass for P. palustris.

117 However, an estimate of individual pollen grain mass may be computed from observations of 118 density, 0.45-0.58 ng pL-1 from several Pinus species (Durham, 1946; Hirose and Osada, 2016), 119 and particle volume, 16.3-57.4 pL also for several Pinus species (Kim et al., 2018). These 120 observations suggest a minimum and maximum weight of 7.3 and 33.4 ng grain ${ }^{-1}$ for Pinus 121 pollen, indicating that the pollen mass flux in net rainfall just from the dogfennel canopy may 122 be $0.1-3.2 \mathrm{~g} \mathrm{ha}^{-1}$. This flux is modest compared to the $\mathrm{kg} \mathrm{ha}^{-1}$ of total pollen deposition from 123 pine forests (Lee et al., 1996; Cho et al., 2003; Lee and Booth, 2003), but this is perhaps 124 unsurprising as some portion certainly reaches its intended destination (cones), directly 125 deposits to the surface or into waterbodies (e.g., Graham et al., 2006), or reaches the surface 126 via other plants' throughfall and stemflow. Still, we note that throughfall and stemflow fluxes 127 are highly spatially variable and may locally concentrate pollen inputs to small areas at the 128 surface (Van Stan et al., 2020). For dogfennel plants at this site, the coefficient of variation for 129 throughfall and stemflow water fluxes were $38 \%$ and $254 \%$ for rainstorms, respectively-and 130 higher for storms with occult precipitation (Gordon et al., 2020). Dogfennel throughfall was 131 observed to exceed stand-scale overstory throughfall by $190 \%$. The especially high spatial 132 variability observed for stemflow resulted in median water inputs near individual plant stems 133 18-200 times more concentrated than the stand-scale overstory throughfall (Gordon et al., 134 2020). Given that pollen grains are rich in N and P (Stark, 1973; Lee et al., 1996; Cho et al., 135 2003) and appear to be bioavailable (Greenfield, 1999; Webster et al., 2008; Filipiak, 2016), 

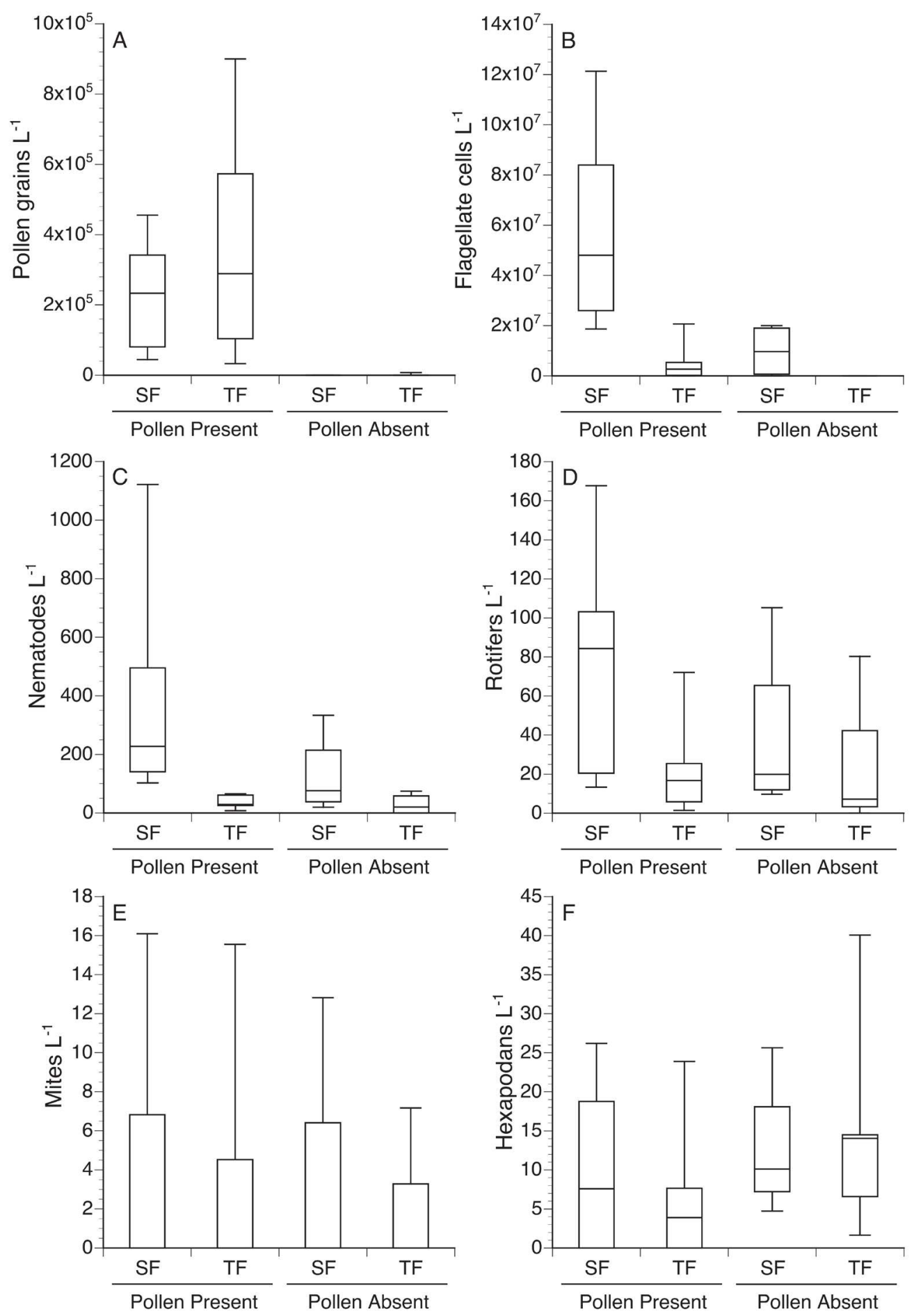

137 Figure 1. Descriptive statistics for concentrations of pollen and biological particulates in throughfall (TF)

138 and stemflow (SF) when pollen was present and absent. Line is the median; Boxes are the interquartile range and lines mark the $10 \%$ and $90 \%$. 
140 spatial concentrations of pollen and water inputs by stemflow and throughfall drip points may

141 be notable localized nutrient subsidies to soils.

Throughfall and stemflow were enriched with other biological particulates, some of

143 which were observed to co-vary with pollen grain presence. There were marked reductions in

144 the concentration of flagellate cells when pollen was absent, where median concentration

145 decreased from $4.8 \times 10^{7}$ to $9.7 \times 10^{6}$ cells $L^{-1}$ for stemflow and $2.7 \times 10^{6}$ to 0 cells $\mathrm{L}^{-1}$ for

146 throughfall (Figure 1b). Median concentrations in nematodes and rotifers were also higher

147 during pollen shedding, especially for stemflow where the median concentration decreased by

$14867 \%$ and $76 \%$ in the absence of pollen for nematodes and rotifers, respectively (Figure 1c-d).

149 Results suggest that pollen deposition may alter the canopy environment such that it supports

150 a larger community of these organisms. Alternatively, since dogfennels begin to senesce leaves

151 in the fall, observed changes in these organismal fluxes in stemflow may relate to seasonal

152 shifts in canopy morphology. Mite and hexapodan (insect and collembolan) concentrations

153 were relatively similar for throughfall (means being 3 mites $\mathrm{L}^{-1}$ and 11 hexapodans $\mathrm{L}^{-1}$ ) and

154 stemflow (means being 4 mites $\mathrm{L}^{-1}$ and $11-13$ hexapodans $\mathrm{L}^{-1}$ ) regardless of pollen presence

155 (Figures 1e-f). Spearman $\rho$ correlations were moderately strong between pollen and both

156 flagellates and nematodes (Table 1). For all the traditionally "aquatic" organisms (flagellates,

157 nematodes, and rotifers) strong-to-moderate correlations were observed (Table 1). Moderate

158 correlation was also observed between hexapodans and mites, but weak or no correlations

159 existed between the other combinations of organisms or pollen (Table 1). Thus, concentrations

160 of traditional aquatic organisms (flagellates, nematodes, and rotifers) similarly vary, while

161 concentrations of the more mobile hexapodans and mites vary similarly with each other. 
Table 1. Spearman $\rho$ correlations between mean pollen, flagellate, and invertebrate concentrations per $\mathrm{L}$ of stemflow and throughfall. Bolded values indicate significant correlations at $p<0.05$.

\begin{tabular}{lcccccc}
\hline & Pollen & Flagellates & Nematodes & Rotifers & Mites & Hexapodans \\
Pollen & & $\mathbf{0 . 4 3}$ & $\mathbf{0 . 3 9}$ & 0.28 & -0.14 & -0.18 \\
Flagellates & & $\mathbf{0 . 7 5}$ & $\mathbf{0 . 4 8}$ & 0.03 & 0.03 \\
Nematodes & & & 0.67 & -0.07 & 0.08 \\
Rotifers & & & & -0.05 & 0.11 \\
Mites & & & & & $\mathbf{0 . 4 7}$ \\
Hexapodans & & & & & \\
\hline
\end{tabular}

This is the first study known to the authors to document the concentration of flagellates in throughfall and stemflow. Flagellates could be the most concentrated of observed

167 particulates in this study, especially in stemflow during pollen shedding where the median was $\sim 50 \times 10^{6}$ cells L ${ }^{-1}$ and could be as high as $120 \times 10^{6}$ cells L-1 (Figure $1 \mathrm{~b}$ ). These flagellate cell concentrations are smaller than bacterial cell concentrations measured in throughfall and

170 stemflow beneath tree canopies via flow cytometry: $10^{7}-10^{9}$ cells $L^{-1}$ (Bittar et al., 2018). Still,

171 the transport of $10^{5}-10^{7}$ flagellate cells $\mathrm{L}^{-1} \mathrm{storm}^{-1}$ from the phyllosphere (where they have long

172 been known to reside: Ruinen, 1961; Bamforth, 1973; Flues et al., 2018) to spatially-localized

173 soil areas may have ecological relevance. Indeed, in other lotic environments, flagellate

174 concentrations are similar-e.g., in temperate rivers concentrations range from $\sim 1-37 \times 10^{6}$ cells

$175 \quad \mathrm{~L}^{-1}$ (Basu and Pick, 1997; Karrasch et al., 2001)-and these organisms are considered

176 ecologically relevant at those concentrations, especially in intermittent streams (Romani et al.,

177 2017) which may be a better analogy for throughfall and stemflow. Of the observed flagellate

178 cells, many were photosynthetic. A few were identified as euglenoids; the remainder lacked

179 clear, distinguishing features, though they were most likely chlorophytes, chrysophytes, and/or cryptomonads. All of these taxa have been previously identified as members of phytotelmata

181 communities (Gebühr et al., 2006; Plachno and Wolowski 2008). 
Few investigations known to the authors have reported the concentration and flux of nematodes, rotifers and/or mites - both report data for stemflow only, one for common central 184 European tree species under natural rainfall (Ptatscheck et al., 2018) and another for a maize 185 cropland under irrigation (Ellsbury et al., 1996). Thus, this is the first report of these organisms' concentrations in both throughfall and stemflow. Stemflow was several times more

187 concentrated in nematodes than throughfall (Figure 1c), which is near or within the range of 188 nematode enrichment previously observed. Ellsbury et al. (1996) uniformly applied the 189 entomopathogenic nematode, Steinernema carpocapsae, and irrigation to control rootworm 190 and found that both irrigation waters and nematodes were significantly concentrated by 191 stemflow, by 3.9 times and 3.1-4.6 times, respectively, compared to above-canopy application 192 amounts. Ptatscheck et al. (2018) stemflow nematode concentrations from large stemflow193 generating tree species (Carpinus betula and Fagus sylvatica: 10 to $>300$ nematodes $\mathrm{L}^{-1}$ ) 194 compared favorably to our dogfennel stemflow samples, especially when pollen was absent (10 195 to $\sim 400$ nematodes $\left.\mathrm{L}^{-1}\right)$. They did not provide a comparison of stemflow concentrations to gross 196 rainfall or throughfall; however, they discussed having "collected an exceptionally large number 197 of small juvenile nematodes" (Ptatscheck et al., 2018). Although Ptatscheck et al. (2018) 198 observed greater concentrations of rotifers than nematodes in tree stemflow, rotifer 199 concentrations in dogfennel stemflow were typically half those observed for nematodes200 perhaps due to the different growth form/habitat of our understory forb. Mite concentrations 201 were similar between our study and Ptatscheck et al. (2018), which generally ranged from 0-16 202 mites $\mathrm{L}^{-1}$ v. 0-20 mites $\mathrm{L}^{-1}$, respectively. 
This is also the first study known to the authors to document the concentration of

204 hexapodans (beyond collembolans) in throughfall and stemflow. Indeed, despite insects being ubiquitous canopy residents, they are typically perceived as a contaminant (and discarded) in

206 past work: e.g., see methods of Dezzeo and Chacón (2006) and discussion by Ponette- González

207 et al. (2020). Given the total $92.9 \mathrm{~L} \mathrm{~m}^{-2}$ of net rainfall observed across 7 studied storms, the 208 median of 5 insects $\mathrm{L}^{-1}$ (hexapodans excluding collembolans) across both fluxes results in an 209 estimated input of 465 insects $\mathrm{m}^{-2}$. The insects found in water samples were, of course, corpses, 210 but diverse (including aphids, ants, and beetles). Regarding collembolans, our average stemflow 211 concentrations were similar to, though slightly smaller than, those reported in Ptatscheck

212 (2018) for the smooth bark trees: 4-6 collembolans $\mathrm{L}^{-1}$ (regardless of pollen) for dogfennel 213 stemflow versus 7 collembolans $\mathrm{L}^{-1}$ for $C$. betula and 8 collembolans $\mathrm{L}^{-1}$ for $F$. sylvatica

214 stemflow. The total flux of these organisms is, of course, increased by those transported in 215 throughfall. As these results are similar and ecologically significant across the only observations 216 available for a cropland (Ellsbury et al., 1996), a forest (Ptatscheck et al., 2018), and our

217 understory site, we re-emphasize the call made by these previous studies for greater 218 investigation of rainfall partitions as critical mediators of biotic particulate exchange between 219 the canopy, litter and soils.

220 Conclusions.

For the five storms that occurred during the Pinus palustris pollen shedding event at our 222 site, total pollen flux through the Eupatorium capillifolium (dogfennel) understory canopy was $22395.6 \times 10^{6}$ grains ha-1 $^{-1}$. Although this represents $0.1-3.2 \mathrm{~g} \mathrm{ha}^{-1}$ season $^{-1}$, throughfall and stemflow 224 beneath dogfennel is highly spatially variable (coefficients of variability were $38 \%$ and $254 \%$ for 
225 throughfall v. stemflow, respectively), which may result in localized particulate inputs. This may

226 especially be true for stemflow, which represented $37 \%$ of the total pollen flux and can be

227 spatially concentrated (18-200 times compared to the stand-scale overstory throughfall).

228 Results suggest that some organisms observed in throughfall and stemflow can be more

229 concentrated during pollen shedding (flagellates, nematodes and rotifers) and others showed

230 no clear change or correlation with pollen (mites and hexapodans). Flagellates and hexapodan

231 concentrations in throughfall and stemflow were reported here for the first time and were

232 found in ecologically relevant quantities. Combined, these biological particulates represent a

233 large flux of materials bringing nutrients to the soil that has barely been studied to-date.

\section{Declarations}

236 Funding. This research was supported by the U.S. Department of Education (Ronald E. McNair

237 Postbaccalaureate Achievement Program).

238 Conflicts of Interest/Competing Interests. The authors declare no conflict of interest.

239 Availability of Data/Code. Data are available in the supplemental materials and anything additional can

240 be provided by request from corresponding author. No code used in this work.

241 Authors' contributions. MG and JTVS conceived and designed the study in consultation with DARG, to

242 complement his hydrometeorological research. DARG designed/deployed field collection devices,

243 collected samples, and analyzed the hydrological data in consultation with JTVS. MG processed samples,

244 performed the microscopy, and analyzed the particulate data. JTVS drafted the initial article with input

245 from all authors. All authors contributed to the manuscript writing.

246 Acknowledgements. The authors thank Karelle Aiken, Issac Taylor, and the rest of the team at the

247 McNair Scholars Program; undergraduate students Madison Logan and Mihir Patel for their help

248 processing samples; Georgia Southern University's Facilities Services for study site access, maintenance

249 and security; and Donát Magyar for insightful conversations about pollen. 
References.

251

252

253

254

255

256

257

258

259

260

261

262

263

264

265

266

267

268

269

270

271

272

273

274

275

276

277

278

279

280

281

282

Aleklett K, Hart M, Shade A (2014) The microbial ecology of flowers: an emerging frontier in phyllosphere research. Botany 92(4):253-266.

Ambika Manirajan B, Ratering S, Rusch V, Schwiertz A, Geissler-Plaum R, Cardinale M, Schnell S (2016) Bacterial microbiota associated with flower pollen is influenced by pollination type, and shows a high degree of diversity and species-specificity. Environ Microbiol 18(12):5161-5174.

Basu BK, Pick FR (1997) Factors related to heterotrophic bacterial and flagellate abundance in temperate rivers. Aquat Microb Ecol 12(2):123-129.

Bamforth SS (1973) Population dynamics of soil and vegetation protozoa. Am Zoologist 13(1):171-176.

Bittar TB, Pound P, Whitetree A, Moore LD, Van Stan, JT (2018) Estimation of throughfall and stemflow bacterial flux in a subtropical oak-cedar forest. Geophys Res Lett 45(3):1410-1418.

Boyer WD (1981) Pollen production and dispersal as affected by seasonal temperature and rainfall patterns. Pollen management handbook 587:2.

Cho YJ, Kim IJ, Kim PG, Lee EJ (2003) Deposition of airborne pine pollen in a temperate pine forest. Grana 42(3):178-182.

Dezzeo N, Chacón N (2006) Nutrient fluxes in incident rainfall, throughfall, and stemflow in adjacent primary and secondary forests of the Gran Sabana, southern Venezuela. For Ecol Manage 234(1-3):218-226.

Doskey PV, Ugoagwu BJ (1989) Atmospheric deposition of macronutrients by pollen at a semiremote site in northern Wisconsin. Atmos Environ 23:2761-2766.

Durham OC (1946) The volumetric incidence of atmospheric allergens: III. Rate of fall of pollen grains in still air. J Allergy Clin Immunol 17(2):70-78.

Filipiak M (2016) Pollen stoichiometry may influence detrital terrestrial and aquatic food webs. Front Ecol Evol 4:138.

Flues S, Blokker M, Dumack K, Bonkowski M (2018) Diversity of Cercomonad Species in the Phyllosphere and Rhizosphere of Different Plant Species with a Description of Neocercomonas epiphylla (Cercozoa, Rhizaria) a Leaf-Associated Protist. J Eukaryotic Microbiol 65(5):587-599.

Gebühr C, Pohlon E, Schmidt AR, Küsel K (2006) Development of microalgae communities in the phytotelmata of allochthonous populations of Sarracenia purpurea (Sarraceniaceae). Plant Biol 8:849-860.

Graham MD, Vinebrooke RD, Turner M (2006) Coupling of boreal forests and lakes: effects of conifer pollen on littoral communities. Limnol Oceanogr 51(3):1524-1529. 
Gordon DAR, Coenders-Gerrits M, Sellers BA, Sadeghi SM, Van Stan II, JT (2020) Rainfall interception and redistribution by a common North American understory and pasture forb, Eupatorium capillifolium (Lam. dogfennel). Hydrol Earth Syst Sci 24(9):4587-4599.

Greenfield LG (1996) Plant pollen production in selected tree species. Canterbury Bot Soc J 31:10-13.

Greenfield LG (1999) Weight loss and release of mineral nitrogen from decomposing pollen. Soil Biol Biochem 31(3):353-361.

Hirose Y, Osada K (2016) Terminal settling velocity and physical properties of pollen grains in still air. Aerobiologia 32(3):385-394.

Hutchison LJ, Barron GL (1997) Parasitism of pollen as a nutritional source for lignicolous Basidiomycota and other fungi. Mycol Res 101(2):191-194.

Karrasch B, Mehrens M, Rosenlöcher Y, Peters K (2001) The dynamics of phytoplankton, bacteria and heterotrophic flagellates at two banks near Magdeburg in the River Elbe (Germany). Limnologica 31(2):93-107.

Kim MJ, Jeon CW, Cho G, Kim DR, Kwack YB, Kwak YS (2018) Comparison of microbial community structure in kiwifruit pollens. Plant Pathol J 34(2):143.

Kwon Y, Lee JT, Kim HS, Jeon C, Kwak YS (2018) Comparative tomato flower and pollinator hive microbial communities. J Plant Dis Protect 125(1):115-119.

Lee EJ, Booth T (2003) Macronutrient input from pollen in two regenerating pine stands in southeast Korea. Ecol Res 18(4):423-430.

Lee EJ, Kenkel N, Booth T (1996) Atmospheric deposition of macronutrients by pollen in the boreal forest. Ecosci 3(3):304-309.

Magyar D, Merényi Z, Udvardy O, Kajtor-Apatini D, Körmöczi P et al (2018) Mycoceros antennatissimus gen. et sp. nov.: a mitosporic fungus capturing pollen grains. Mycol Prog 17(12):33-43.

Masclaux H, Perga ME, Kagami M, Desvilettes C, Bourdier G, Bec A (2013) How pollen organic matter enters freshwater food webs. Limnol Oceanogr 58(4):1185-1195.

Millerón M, De Heredia UL, Lorenzo Z, Perea R, Dounavi A et al (2012). Effect of canopy closure on pollen dispersal in a wind-pollinated species (Fagus sylvatica L.). Plant Ecol, 213(11):17151728.

Plachno BJ, Wolowski K (2008) Algae commensal community in Genlisea traps. Acta Societatis Botanicorum Poloniae 77(1):77-86. 
315 Ponette-González AG, Van Stan II JT, Magyar D (2020) Things Seen and Unseen in Throughfall 316 and Stemflow. In: Precipitation Partitioning by Vegetation. Springer, Cham, pp. 71-88.

317 Ptatscheck C, Milne PC, Traunspurger W (2018) Is stemflow a vector for the transport of small 318 metazoans from tree surfaces down to soil? BMC Ecol 18(1):43.

319 Romaní AM, Chauvet E, Febria C, Mora-Gómez J, Risse-Buhl U, Timoner X et al (2017) The biota 320 of intermittent rivers and ephemeral streams: prokaryotes, fungi, and protozoans. In:

321 Intermittent Rivers and Ephemeral Streams. Academic Press, London, pp. 161-188.

322 Rösel S, Rychła A, Wurzbacher C, Grossart HP (2012) Effects of pollen leaching and microbial 323 degradation on organic carbon and nutrient availability in lake water. Aquat Sci 74(1):87-99.

324 Ruinen J (1961) The phyllosphere: I. An ecologically neglected milieu. Plant Soil 15:81-109.

325 Stark N (1973) Nutrient Cycling in a Jeffrey Pine Forest Ecosystem. Montana Forest and 326 Conservation Experiment Station. University of Montana, Missoula, Montana.

327 Van Stan II JT, Hildebrandt A, Friesen J, Metzger JC, Yankine SA (2020) Spatial Variability and 328 Temporal Stability of Local Net Precipitation Patterns. In: Precipitation Partitioning by 329 Vegetation. Springer, Cham, pp. 89-104.

330 Van Stan II JT, Ponette-González AG, Swanson T, Weathers KC (2021) Concepts and Questions: 331 Throughfall and stemflow are major hydrologic highways for particulate traffic through tree 332 canopies. Front Ecol Environ, in press.

333 Webster EA, Tilston EL, Chudek JA, Hopkins DW (2008) Decomposition in soil and chemical 334 characteristics of pollen. Eur J Soil Sci 59(3):551-558. 


\section{Figures}
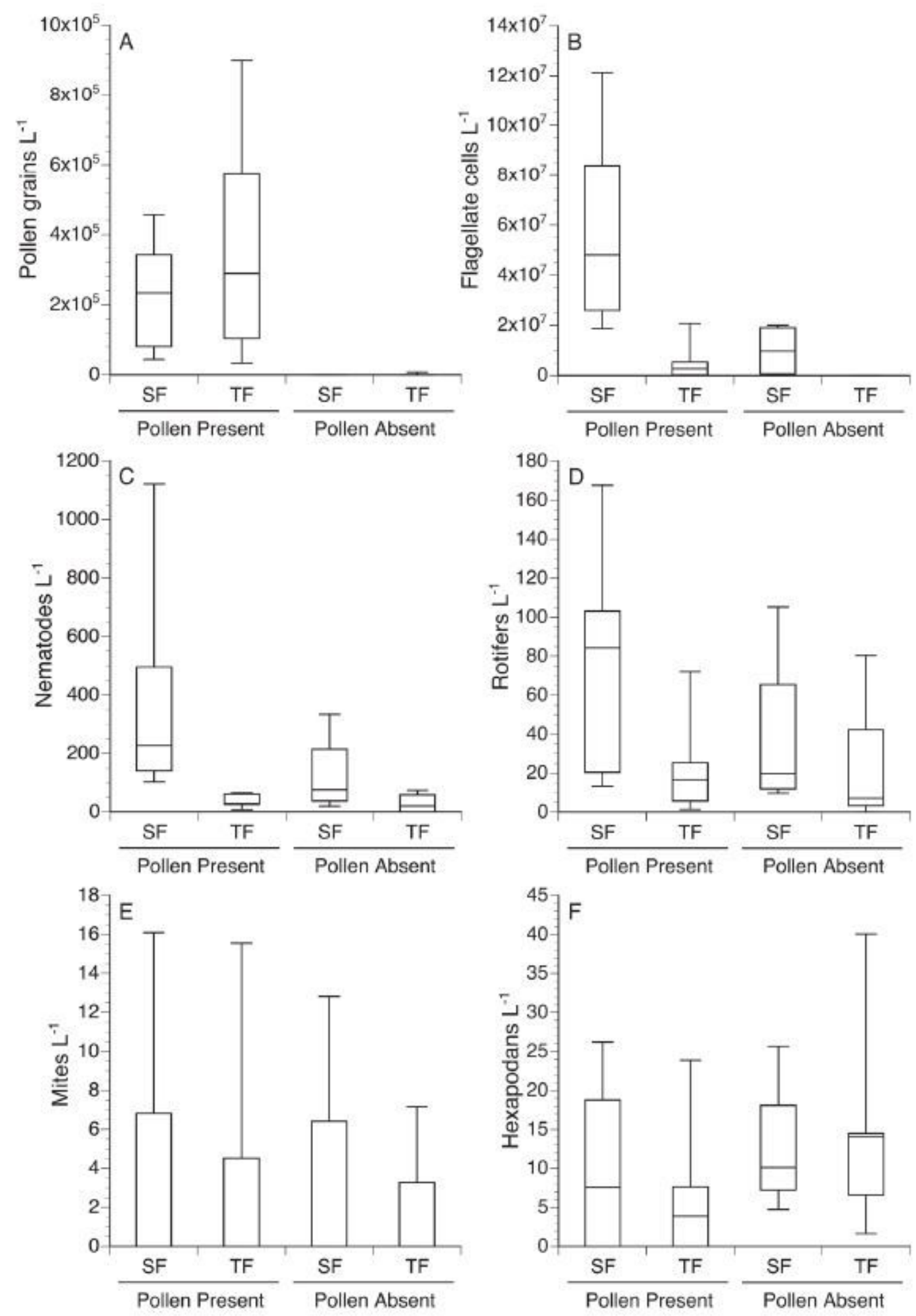

Figure 1

Descriptive statistics for concentrations of pollen and biological particulates in throughfall (TF) and stemflow (SF) when pollen was present and absent. Line is the median; Boxes are the interquartile range and lines mark the $10 \%$ and $90 \%$. 


\section{Supplementary Files}

This is a list of supplementary files associated with this preprint. Click to download.

- SupplementGuidoneetalLivingParticulates22Jan2021.pdf 